\title{
There are Peacebuilding Tasks for Everybody
}

\author{
Chadwick F. Alger
}

(Professor Emeritus, Ohio State University)

\section{| 요약 |}

약 25년 전 쯤 요한 갈통이 우리가 이 주제를 어떻게 접근을 해야 하는지 많은 것을 시사했습니다. 모든 사람들이 할 일이 있다고 말을 했습니다. 긍정 적인 평화, 그러니까 구조적인 폭력을 뛰어넘는 긍정적인 평화와 그리고 또 부정적인 평화, 직접적인 폭력을 극복하는 그런 평화에 기여할 바가 모두에 게 있다고 말을 했습니다. 그리고 그 이후 그 분의 주장이 점점 더 명백히 드 러났습니다. 더 많은 사람들 그리고 또 더 많은 분야의 사람들이 평화와 관련 된 활동에 기여를 하고 있습니다. 또 국경을 넘는 활동을 하고 있습니다. 그 런데 이들이 더 나은 세상을 만드는데 기여를 하는 것을 아직 소수만이 인지 를 하고 있습니다. 미디어는 아직까지 공식적인 정부가 더 실패했다, 평화를 구축하는데 실패를 했다는 소식만 보도를 하고 있습니다.

그런데 평화를 구축했다는 성공사례는 그렇게 보고되지 않고 있습니다. 수천의 사람들이 평화활동을 하고 있고, 그리고 또 평화 구축활동을 하고 있 다는 것이 보도가 되고 있지 않다는 것입니다. 그럼에도 불구하고 요한 갈통 의 시사점을 반영하는 그런 움직임이 보이는 것이 정말 반가운 일입니다. 바 로 평화의 문화를 위한 움직임입니다. UN 총회는 평화의 문화를 일련의 가 치행동, 그리고 또 삶의 방식으로서 폭력을 배제하고 그리고 또 갈등을 방지 하며 그 근원적인 문제를 해결하고, 그리고 또 대화를 통해서 개인간, 그룹 간, 국가간의 협상을 유도를 하는 행위라고 정의를 했습니다. 유네스코가 평 화 문화를 위한 국제적인 움직임을 지금 지지를 하고 있다는 것도 이상하지 
4 | 국제평화 제4권 2호(2007. 12)

않습니다. 유네스코 헌장을 보면 전쟁은 사람의 마음으로부터 비롯되기 때 문에 사람의 마음으로부터 평화를 위한 방어책을 건설을 해야 한다고 적혀 있습니다. 그리고 또 평화연구를 보면 모든 사람들이 할 일이 있습니다. 평화 의 문화를 만드는데 모든 사람이 기여를 할 바가 있다는 것입니다. 그런데 불 행하게도 오직 소수의 사람들만이 이 지식을 깨닫고 있습니다.

그래서 저는 오늘 우리의 평화구축을 위한 역할에 팽창하는 지식이 세 가 지 역할이 있다고 지적을 하고 싶습니다. 먼저 저는 이 시간을 통해 참석자들 에게 우리가 평화를 위해서 무슨 일을 하고 있다고 인지를 하게끔 할 것이고, 두 번째로는 서로간 평화를 구축하기 위한 역할이 어떻게 상호 연계되어 있 는지 말씀을 드릴 것이고, 마지막으로 연구자들이 각각에 평화구축 역할을 더 잘 이해하고 상호의존도를 더 잘 이해하게끔 말씀을 드리겠습니다. 평화 구축과정에서 먼저 지적할 것은 UN이 역할을 하고 있다는 점입니다. 두 번 째로는 $\mathrm{NGO}$ 와 시민사회 그리고 비즈니스 그리고 또 지역정부가 $\mathrm{UN}$ 시스 템 외에 이런 주체들이 어떻게 평화에 기여를 하고 있다는 것입니다. 그리고 마지막으로 지역 공동체가 지역 갈등이 더 큰 갈등으로 진전되는 것을 막고 있습니다.

수 백 년 동안 경험을 통해 위기가 벌어진 후 그 사후 대책에 부족함을 깨 달았습니다. 그리고 $\mathrm{UN}$ 의 60년 동안 경험을 보면 $\mathrm{UN}$ 시스템의 의제가 횔 씬 더 넓어졌다는 것을 알 수 있습니다. 그래서 이제 '갈등 이후 평화 구축' (post conflict peace making)과 '장기적인 평화구축(long term peace building)이라는 용어들이 이제 자주 사용되고 있다는 것을 알 수 있습니다. $\mathrm{UN}$ 시스템을 지금 보면 50여개의 주체들이 평화구축역할을 하고 있습니다. 그리고 또 많은 분들은 54개의 UN 기구들이 글로벌 가버넌스를 반영을 한 다고 생각을 합니다. 이런 관점을 보면 모든 글로벌 가버넌스 결정이 평화 구축에 어떤 영향을 미치는지 볼 수 있습니다. 이렇게 간략하게 살펴보면 모든 직종의 사람들이 $\mathrm{UN}$ 시스템에 기여를 할 바가 있고 또 자신들이 개입 하겠다고 선택을 할 수 있다는 것을 알려주고 있습니다. 그리고 모든 학문 의 연구자들이 어떻게 더 이런 개입을 다 잘 조명을 할 수 있는지 생각해 볼 
바가 있습니다. 지금 평화구축을 위해 주체들이 훨씬 더 많은 기여를 하고 있습니다. 지금 회원국이라던지 사무처 보다 더 많은 주체들이 개입을 하고 있습니다.

$\mathrm{NGO}$ 와 시민사회의 역할, 그리고 또 비즈니스와 지역정부의 역할을 살펴 보도록 하겠습니다. 현재 2718 개의 $\mathrm{NGO}$ 들이 $\mathrm{UN}$ 의 경제사회이사회의 자문 을 받고 있고 그리고 또 약 400 여개의 $\mathrm{NGO}$ 가 지속가능한 발전위원회 (Commission On sustainable Development)에 참여를 하고 있습니다. 그리 고 또 1500 개의 NGO가 공공정보분과(Department of Public Information) 에 관여를 하고 있습니다. 공공정보분과는 $\mathrm{NGO}$ 가 지금 참여를 하고 있고 정보를 확산을 하는데 도움을 드리고 있습니다. 곧 대중이 UN의 목적을 더 잘 이해를 하기 위해서 정보를 제공을 하는 역할을 공공정보분과가 하고 있 습니다. 수백만명이 이런 단체 NGO 들의 회원이죠. 그리고 또 이들이 UN에 지금 참여를 하고 있습니다. 그렇지만 이 참여사실을 인지를 하는 사람들은 그렇게 많지 않습니다. UN의 웹사이트를 보면 “비즈니스 커뮤니티가 UN이 1945년 창립된 이래 많은 기여를 했다'라고 명시를 하고 있습니다. 그리고 다수의 UN단체들이 재계와 성공적으로 협력을 한 경험을 가지고 있습니다. 그리고 또 최근 정치 경제적인 변화 때문에 지금 이런 협력적인 관계가 더욱 추구가 되고 있습니다.

1999년 UN 사무총장 코피 아난은 재계의 지도자들이 국제적인 이니셔티 브에 동참하라고 촉구를 했습니다. 바로 세계적 접촉(global contact)에 동참 을 하라고 요구를 한 것입니다. 이렇게 되면 회사들과 UN기구들, 그리고 노 동기구들과 시민사회들이 국제 원칙을 지지를 하게 되는 것입니다. 인권, 노 동, 환경, 그리고 또 반부패 쪽에서 같이 연계를 하자는 촉구였습니다. 현재 6 개 UN기구에 세계적 접촉 사무실을 두고 있고, 그리고 또 100 여개국의 2900 여개의 회사들이 이제 $\mathrm{UN}$ 의 세계적 접촉에 동참을 하고 있습니다. 주권국가 들은 이런 사실을 좀 놀라워 할 수도 있겠지만 지금 지역정부들도 UN시스템 에 많이 동참을 하고 있습니다. 도시들이 코피 아난 사무총장의 아젠다에 올 라와 있습니다. 1999년에 지역정부에 더욱 많은 권위를 제공하고 있고 이제 
6 | 국제평화 제4권 2호(2007. 12)

세계가 도시 새천년을 맞이할 때 생기게 된 문제들을 다뤄야 된다고 말을 했 습니다. 6개월 전 UN 지방정부자문회의(Advisory Community of Local Authority)가 베니스에서 열렸습니다. 이 회의는 유엔인간거주위원회(UNHabitat)가 주최를 한 것이고 또 전 세계의 시장들이 참여를 했습니다. 그리 고 또 지방정부 단체들의 회장들도 참여를 했습니다.

지금 시민단체 재계 그리고 또 지방정부가 평화를 구축을 하는데 역할이 있습니다. UN체제 밖에서 할 일이 있다는 것입니다. 첫 번째로 국제적인 비 정부기구들입니다. 두 번째로 지역사회 움직임, 세 번째 재단이고, 네 번째는 미디어, 다섯 번째는 교회 노조, 소비자단체와 지성인들입니다. 여섯 번째 주 체는 정부간 그리고 지방정부간의 단체입니다. 일곱 번째로는 정부의 행정 기관들입니다. 그리고 또 입법기관도 주체로 꼽혔습니다.

많은 사람들이 커뮤니케이션 쇼핑, 레크리에이션 그리고 또 투자활동을 매일 매일 합니다. 사람들이 이런 활동을 통해 재계에 영향을 미치고 인권에 영향을 미치고 또 평화관련 문제에 영향을 미치고 있습니다. 그래서 어떻게 이들의 활동이 세계평화에 기여를 할 수 있을까 생각을 해봐야 합니다. 또 글 로벌 멤버십을 가진 도시단체들이 특정 쟁점들을 다루고 있습니다. 예를 들 면 도시 정상회담과 메트로폴리스라는 회의가 있습니다. 그리고 또 지방환 경구상국제위 원회 (ICLEI: The International Council for Local Environmental Initiatives) 가 지역 국제적인 환경문제를 지역행위로 풀자고 나서고 있습니다. 그리고 도시간의 단결을 통한 평화움직임이 히로시마와 나가사키 시의 주도로 생겨났습니다. 그리고 또 아랍도시기구(ATO:Arab Towns Organization)와 유로시티 그리고 또 중남미 지역의 도시단체들이 이런 움직임에 동참을 하고 있습니다.

이런 지방정부들이 이제 보다 많이 평화, 그리고 또 환경, 그리고 또 자치 그 외의 많은 쟁점에도 관심을 가지고 있습니다. 도시들이 힘을 합해서 이제 비무장지대 등을 위한 활동을 하고 있고 또 지역 군사 생산, 인권, 인종분리 주의에 맞서고 있습니다. 지역정부, 문화, 정치가 글로벌한 패턴에 영향을 미 친다고 인식을 하고 있습니다. 그래서 어떻게 평화연구자들이 지역정부와 
그 시민을 도와 지역정책이 어떻게 글로벌패턴을 지지를 할 수 있는지 생각 을 해야 됩니다. 유럽연합이 단적인 예입니다. 평화 연구자들과 평화주의자 들은 이런 활동을 통해 미래의 옵션을 타진해 봐야 되고, 그리고 또 지역정 부가 어떻게 국제 거버넌스에 영향을 미칠 수 있는지 생각을 해 봐야 될 것 입니다.

최근 평화 연구자들 특히 국제적 관심을 가진 평화 연구자들이들이 국내 에서 지역분쟁해결책을 살펴봤습니다. 여기에는 지역 갈등을 학교, 지역사 회, 그리고 재계와 법원에 서로 다룰 수 있는 프로그램을 개발하는 게 있고, 또 두 번째로는 학교에서 평화교육을 하는 것, 세 번째로는 평화의 문화에 합 당한 학교문화를 만들어 나가는 것입니다. 이런 국지적인 평화활동들은 정 치적인 국경들을 뛰어 넘습니다. 그래서 지역에서 국제관계로 나가고 있는 것입니다. 따라서 이 잠재력을 최대 발현시키기 위한 연구가 필요한 상황입 니다. 그리고 지방차원에서 개입을 한 분들이 자신들의 지역평화건설 활동 이 어떻게 국지적인 영향을 미치는지 잘 깨달아야 된다는 것입니다. 이런 모 든 활동을 보면 이미 많은 그룹들, 단체들 시민들이 갈등방지, 그리고 평화구 축을 위해서 많은 일을 하고 있다고 시사 받을 수 있습니다.

그러면 이런 인지도를 어떻게 더 높이고, 또 그들의 기여도를 어떻게 더 높 일 수 있을까요? 사실 모든 사람들이 21세기 평화구축에 해야 할 일이 있습 니다. 그리고 또 이런 모든 임무들을 다 아울러서 글로벌 거버넌스 비젼으로 만들어 내야 되고, 또 평화를 위한 문화로 탄생을 시켜야 됩니다.

우리는 과거에 가졌던 국가 위주의 세계관을 이제 바꿔야 합니다. 우리가 세계관을 좀 더 단순화시킴으로써 평화구축을 위한 주체들의 역할을 이해를 할 수 있습니다. 이제 저희가 현실적인 접근법을 취해 평화구축 활동을 통합 시켜야 합니다. 그래서 그 기회를 잡아야 된다는 것입니다. 21세기에 더 평화 로운 세상을 만들 수 있는 기회가 더 많습니다. 모든 사람들이 동참을 해야 됩니다. 


\section{8 | 국제평화 제4권 2호(2007. 12)}

I am truly delighted to have the opportunity to provide the keynote address to an international conference on a very significant and challenging topic: World Peace in the $21^{\text {st }}$ Century: Its Direction and Prospect. Over twenty-five years ago Johan Galtung provided us an insight on how we must approach this topic. He informed us that there are "tasks for everybody." in the pursuit of peace that includes both positive peace (overcoming structural violence) and negative peace (overcoming direct violence). (Galtung, 1980, 396) Since that time, because of learning through both practice and research, the truth of his assertion is ever more apparent. More and more people, in an increasing range of professions and disciplines, are participating in peace related activities that flow across state borders. Unfortunately, the potential that they offer for building a more secure world is perceived by very few. The media is focused primarily on events caused by the failures of officials to provide a secure world for their inhabitants. Day after day, month after month, and sometimes year after year, details of the same failures are reported, but successes are rarely reported. Also largely ignored are the achievements of thousands of people engaged in peacemaking and peacebuilding around the world.

Nevertheless, it is very encouraging that a movement has emerged that reflects Johan Galtung's vision, the movement for "A Culture of Peace". The UN General Assembly has defined the Culture of Peace as "a set of values, attitudes, modes of behavior and ways of life that reject violence and prevent conflicts by 
tackling their root causes to solve problems through dialogue and negotiation among individuals, groups and nations." It should not be surprising that UNESCO has been fostering a global Movement for A Culture of Peace, in the light of the fact that UNESCO's constitution opens with these words: "since wars begin in the minds of men, it is in the minds of men that the defences of peace must be constructed."

Peace research that has emerged in the last several decades makes it ever more obvious that there are "tasks for everybody" in developing a "culture of peace." Unfortunately, very few people, including many actually involved in efforts to cope with seriously disruptive conflict, are aware of this expanding knowledge. My overview today of our growing knowledge about peacebuilding roles has three goals: (1) briefly describe these roles so that potential participants can perceive them, (2) provide a broad overview that will enable those engaged in one role to perceive how their role is interdependent with an array of other roles, (3) challenge peace researchers to more adequately cover the wide array of peacebuilding roles and their interdependence.

Today I will first briefly describe how the expanding peacebuilding agenda of the UN System now involves people from an ever wider range of professions and disciplines, and increasingly involves NGOs/civil society, the business community and local authorities. Second, I will describe existing roles played by members of NGOs/civil society, business, and local authorities in world politics outside the UN System. Third, I 
국제평화 제 4 권 2호(2007. 12)

will describe efforts to educate people in local communities how to prevent local conflicts from causing serious disruption. Not only will this make local communities more peaceful, but it will also to create a "laboratory" in which local people can learn how to cope with international conflicts in the same way.

After many centuries of experience we have learned of the shortcomings of responding to crises after they happen, instead of focusing on long- term preventive action. League of Nations experience, and Sixty years of UN experience, has led to an ever broader UN System agenda that that now is frequently referred to as post-conflict peacemaking and long-term peacebuilding. As a result the organization chart of the UN System now includes over fifty units that perform peacebuilding roles. Fifty-four functions appear in the names of these agencies. Of course, atomic energy, chemical weapons, disarmament, nuclear test ban, and peacekeeping are included But also included are agriculture, climate change, crime prevention, drug control, environment, forests, health, human rights, indigenous issues, labor, refugees, telecommunications, and tourism. (Alger, 2006, 5-15)

Many perceive the fifty-four UN functions to reflect the growing reach of global governance in response to the ever widening geographic borders of governance problems. This perspective very usefully reveals that it is essential that we ponder the possible impact of all global governance decisions on peacebuilding. Of course, all of these functions are also performed by regional organizations of states, by departments of 
the governments of states and by departments in many provincial and local governments. Obviously, those aspiring to be peacebuilders face very complex challenges. On the other hand, simplification that ignores the complexity of reality ignores the full array of peacebuilding opportunities. This quick overview challenges those involved in all professions to ponder the roles that their profession plays in the UN System and their personal options for involvement. It also challenges researchers in all academic disciplines to ponder how they might more adequately illuminate these involvements

Perception of alternatives for participating in peacebuilding can also be attained by examining the escalating involvement of actors other than member states, and members of secretariats, in the UN System. We will examine the activities of NGOs/civil society, business and local authorities. Currently there are 2719 NGOs in consultative status with the Economic and Social Council and some 400 NGOs accredited to the Commission on Sustainable Development, a subsidiary body of ECOSOC. Fifteen hundred NGOs are associated with the Department of Public Information (DPI). DPI helps these NGOs gain access to, and disseminate information about, issues in which the United Nations is involved, so that the public can better understand the aims and objectives of the UN and support its work. Millions of people are members of these organizations that are representing them at the UN, but few are aware of this.

Many of these NGOs are now widely involved in the political process at UN Headquarters in New York, and at the 
12 | 국제평화 제4권 2호(2007. 12)

headquarters of other UN System agencies around the world. In addition, NGO presence at UN conferences at sites around the world has had significant feedback on evolving NGO participation in the UN System. Another significant venue for NGO participation in inter-state decision-making that is closely linked to the UN System is conferences called for the drafting of treaties. The significant contribution of NGOs in the development of the landmine treaty was recognized by awarding of the Nobel Peace Prize to the leader of The International Campaign to Ban Land-mines. This successful campaign linked one thousand NGOs in 60 countries, largely through e-mail. During negotiations on the International Criminal Court Treaty, "NGOs participated informally, but effectively, alongside governments in a high-level negotiating process.

The UN web site states: "The business community has played an active role in the United Nations since its inception in 1945. A number of UN organizations have a successful history of cooperating with business. Recent political and economic changes have fostered and intensified the search for collaborative arrangements." (www.un.org/partners/business) In 1999 Secretary-General Kofi Annan challenged business leaders to join an international initiative - the Global Compact - that would bring companies together with UN agencies, labor and civil society to support universal principles in the areas of human rights, labor, the environment and anti-corruption. There are now global Compact offices in six UN agencies. Over 2,900 
businesses in 100 countries around the world are now involved in the UN Global Compact. The peace mission of the Global Compact is defined in Enabling Economies of Peace: Public Policy for Conflict-Sensitive Business. In April 2004 SecretaryGeneral Kofi Annan addressed an open debate of the Security Council on the role of business in conflict prevention, peacekeeping and post-conflict peacebuilding.

Surprising as it might seem for an organization of states, there is now increasing involvement of local governments in the UN System. Cities were even on the agenda of Secretary General Kofi Annan, who said in 1999 that local governments should be given more authority to deal with problems that come with explosive growth as the world enters the "urban millennium." Only six months earlier a UN Advisory Committee of Local Authorities was established in Venice, at a meeting called by the Head of UN-Habitat (UNCHS), and attended by mayors from all over the world and presidents of international associations of local authorities. In "Cities Localize Global Processes", an article by Rasna Warha, Editor in Chief of Habitat Debate published by UNCHS (Habitat), she expresses a view of world politics that is very surprising to those who assume a state-centered view: "The world is no longer a community of States, but an increasingly borderless network of interconnected cities ..." (Warah, 2001)

Obviously, there are peacebuilding tasks for civil society, business and local authorities in world politics beyond the UN System. Keck and Sikkink, in Activists Beyond Borders, use the term "advocacy network" in their volume on the transnational 
14 | 국제평화 제4권 2호(2007. 12)

activities of NGOs/civil society, with this explanation: "By importing the network concept from sociology and applying it transnationally, we bridge the increasingly artificial divide between international and national realms. ...The networks we describe in this book participate in domestic and international politics simultaneously, drawing on a variety of resources, as if they were part of an international society." (Keck and Sikkink, $1998,4)$ The complexity of the political processes in which organizations that are the focus of this volume are involved is not only a result of the 'sheer diversity' of those organizations working for social and political change, but also a result of the array of other actors with which they must interact. Keck and Sikkkink list seven major actors in "transnational advocacy networks": (1) international and domestic nongovernmental research and advocacy organizations, (2) local social movements, (3) foundations, (4) the media, (5) churches, trade unions, consumer organizations, and intellectuals, (6) parts of regional and international intergovernmental organizations, (7) parts of the executive and/or parliamentary branches of governments. (Keck and Sikkink, 1998, 9)

NGOs/civil society engaged in a diversity of field activities are increasingly informed about the ways in which their activities can impact peacebuilding. For example, In Do No Harm: How Aid Can Support Peace--or War (1996), Mary Anderson asserts that the impact of aid is not neutral. She asks, how can humanitarian or development assistance be "given in conflict situations in ways that rather than feeding into and exacerbating 
the conflict help local people to disengage and establish alternative systems to deal with the problems that underlie conflict?"

In the light of the prominent use of religious differences as a basis for waging conflict and war, research illuminating how religion can be employed as a peace tool is extending visions of roles that religious organizations can play in peacebuilding. $\mathrm{R}$. Scott Appleby, in The Ambivalence of the Sacred: Religion, Violence and Reconciliation (1999), asserts that religion's ability to inspire violence is intimately related to its equally impressive power as a force for peace.

Our brief overview of business in the UN System reflected diverse dimensions of business involvement in world politics that have been largely ignored by the mainstream of international relations research; but the international economic roots of peacelesness has received growing attention in peace research. (Jeong, 2000, 87-93) Significant is the recent emergence of literature on the potential roles of business in "conflict prevention" Wenger and Mockli, in Conflict Prevention: The Untapped Potential of the Business Sector, present a typology of roles that focus on "corporate economic peace building", including contractural agreements for supplying services to local or international actors involved in conflict prevention, willingness to take on additional risk in the cause of conflict prevention, coordinating their actions with other actors engaged in conflict prevention, and offering their extensive economic experience and know-how to any actor seeking to create 
16 | 국제평화 제4권 2호(2007. 12)

economic opportunity in conflict-prone countries

Christopher L. Avery, in Business and Human Rights in a Time of Change, 2000, "identifies sources of pressure on business to act responsibly, how this pressure is intensifying and how business is responding." One example is human rights training for employees by BP Amoco whose internet sites provide employees with guidance on human rights issues and contact information on international human rights and development organizations. In another example, nine major US retailers agreed to help fund an independent monitoring of their factories in the Northern Marianas Islands in 1999.

All people live their daily lives in communication, transportation, housing, shopping, recreation, investment, and other activities that involve them in the impact of business on buman rights and other peace related issues. How can peace researchers help people to make their business involvements supportive of a peaceful world?

Particularly after World War II, many local people attempted to facilitate international understanding and peaceful relations through Sister City relationships. Some Sister City relationships have evolved into local efforts that replace or supplement foreign activities of states. Prominent here are efforts by "First World" cities to facilitate the economic development of their Sister Cities in the "Third World", as exemplified by Towns and Development and Municipal International Cooperation (MIC) programs in Europe. In the US, and elsewhere, local campaigns have declared local communities nuclear free zones, and have 
demonstrated against local military production, and local military bases housing foreign troops.

Another challenge to traditions of the state system has been efforts to mobilize local people in order to impact domestic policies of foreign states. An obvious example is campaigns against apartheid in South Africa that took place in many countries. Closely related are local efforts to change the international activities of business in which government is not significantly involved. An example is the In-Fact Campaign against the marketing of infant formula in the Third World, primarily waged against the Nestle Corporation and a few other companies. (Alger, 1999)

Governments of cities have joined together to create both global and regional organizations of municipalities, some with general purposes and some with more limited agendas. Members of United Cities and Local Governments, with headquarters in Barcelona, include both individual cities and national associations of local governments. It is "dedicated to promoting the values, objectives and interests of cities and local governments across the globe." With members from 127 countries, it aspires "to be the united voice and world advocate of democratic local self-government, promoting its values, objectives and interests, through cooperation between local governments, and within the wider international community."

There are also organizations of cities with global membership that have a specific focus. Organizations of larger cities include the Summit conference of Major Cities of the World (SUMMIT) 
18 | 국제평화 제4권 2호(2007. 12)

and METROPOLIS. The International Council for Local Environmental Initiatives (ICLEI) is dedicated to the prevention and solution of local, regional and global environmental problems through local action. The World Council of Mayors for Peace Through Inter-city Solidarity was initiated by the cities of Hiroshima and Nagasaki.

Regional organizations of municipalities include Arab Towns Organizations (ATO), CITYNET (Asia and Pacific), Eurocities, Red de Associationes de municipios de America Latina, Union des Villes Africaines (UVA), and Union of the Baltic Cities.

Finally, in fulfillment of its support of democracy, the Council of Europe (COE) created The Congress of Local and Regional Authorities of Europe (CLRAE) in 1994. Although only having an advisory role, it does establish the CLRAE as a third component, along with the Parliamentary Assembly and the Committee of Ministers, in the Council of Europe. Its responsibilities include helping new member states to make progress in establishing effective local and regional self-government. The European Union (EU) has a somewhat similar body. The Committee of the Regions (CoR) is the political assembly that provides local and regional authorities with a voice at the heart of the European Union.

This very brief overview of the involvement of local authorities in world politics has revealed that there are a number of worldwide and regional organizations of local authorities focused on peace, environment, local self-government and other issues. Cities have joined together in campaigns on issues such 
as nuclear free zones, local military production, local military bases, and Apartheid. In the light of the fact that "It is not just that cities are affected by global forces, but that local economies, cultures, and politics also affect global patterns", how might peace researchers assist local authorities and their citizens in developing local policies that affect global patterns supportive of peaceful global patterns? Furthermore, the development of a Congress of Local and Regional Authorities in the Council of Europe, and a Committee of the Regions in the European Union, challenges peace researchers, and peace activists, to ponder possible future options and trends in the participation of local authorities in the governance of world regions and in global governance.

\section{Preparing people to cope with local conflict within states}

Recently some peace researchers with an international focus have seen value in linking with a growing related field that is focused on local arenas of conflict within states, including schools, local communities, business, and courts. One example is The Ohio Commission on Dispute Resolution and Conflict Management. "Focused on four program areas -- educational institutions, state and local government, courts, and communities -- the Commission works to positively affect the lives of all Ohio citizens by providing dispute resolution and conflict 
국제평화 제4권 2호(2007. 12)

management training, consultation and technical assistance in designing dispute resolution programs, and facilitation and mediation services." (www.disputeresolution.ohio.gov) Some involved in peace research with a global focus perceive that knowledge and experience acquired in coping with local dispute resolution and conflict management enhances the ability of people to cope with these issues in larger geographic arenas.

In response to both of these concerns an International Network for Conflict Resolution Education and Peace Education (INCREPE) has been created. INCREPE sees its role as "prevention of conflict by stakeholders at all levels, including international organizations, governments, education administrators, teachers and faculty, parents, students and members of the local community." Included in the goals of INCREPE are conducting research to illustrate the effectiveness of conflict resolution education and peace education, and networking across groups, including government, nongovernmental, and civil society organizations and educational institutions. INCREPE is fulfilling an important dimension of "A culture of Peace" by fostering a culture of peace through education

Presently knowledge is expanding about opportunities for developing local "cultures of peace." They include (1) the development of programs for coping with local conflicts in schools, local communities, business and courts, (2) peace education in schools, and (3) the development of school cultures 
that are compatible with "cultures of peace." These local peace activities are relevant not only for building local peace, but also are potential for building peace that transcends political borders from local to global. Research is needed that illuminates this potential and how it can be maximized. It will help those locally involved to acquire understanding of the wide geographic implications of their local peacebuilding activities.

\section{Conclusion}

In our introduction to we stated that we have three goals: (1) to describe the broad array of peace building roles that now exist so potential participants can perceive opportunities for participation, (2) to enable those involved in one peace building role to perceive the system of peace building roles and ponder how their role is linked to, and interdependent with, others, (3) to challenge peace researchers to more adequately cover the wide array of peace building roles and their interdependence.

An overview of the many peacebuilding roles in the UN System challenges those involved in all professions to ponder the roles that their profession plays in the UN System and their personal options for involvement. It also challenges researchers in all academic disciplines to ponder how they might more adequately illuminate these peacebuilding roles and evaluate their effectiveness.

An overview of the range of roles performed by several 
22 | 국제평화 제4권 2호(2007. 12)

thousand NGOs/civil society organizations in the UN System challenges us to ponder the fact that most members of these organizations are unaware that they are represented in decisionmaking throughout the UN System. How can they be made more aware, and become actively involved?

Over 2,900 businesses in 100 countries around the world are involved in the UN Global Compact, an effort to motivate business to support universal environmental and social principles. Most people in local communities around the world are involved with these companies, as customers, employees and investors. How can they be enabled to perceive roles that they can play in fulfilling the goals of the UN Global Compact?

Participation of local authorities in the UN System reflects the fact that many local authorities perceive the need for involvement in the UN System. How can more local authorities, and local citizens, become aware of this perceived need for direct involvement of local authorities in the UN System?

Our overview of our expanding knowledge about peacebuilding roles in world politics beyond the UN System provided these insights.

The peacebuilding tasks performed by NGOs/Civil society in world politics range across "transnational advocacy networks", humanitarian assistance roles, development assistance roles, religious roles, and a wide array of peacebuilding roles in the field. How can analysis of these activities by peace researchers help them to become more effective and to attract wider participation? 
In the light of the fact that cities are not only affected by global forces, but at the same time local economies, cultures, and politics also affect global patterns, how might peace researchers assist local authorities and their citizens in developing local policies supportive of peaceful global patterns?

All people live their daily lives in communication, transportation, housing, shopping, recreation, investment, and other activities that involve them in the impact of business on human rights and other peace related issues. How can more people be enabled to make their business involvements more supportive of a peaceful world?

Our overview of the expanding knowledge about peacebuilding roles concluded with information on opportunities for developing local "cultures of peace." How can education for, and participation in, local dispute resolution and conflict management be made more useful for coping with these issues in larger geographic areas?

Obviously there are Peacebuilding tasks for everybody in the $21^{\text {st }}$ century. Of course, it is indeed a challenging task to incorporate this complicated array of tasks into a vision of global governance supportive of a "culture of peace." But this must be done. In developing our earlier state-centered views of the world, we tended to simplify our view of the world so we could understand it. Now we must take a more realistic approach, and attempt to integrate the peacebuilding opportunities that these challenging complexities make available. 
24 | 국제평화 제4권 2호(2007. 12)

There certainly is much potential for building a World that is more peaceful in the $21^{\text {st }}$ Century! Everybody must participate! 


\section{References}

Alger, Chadwick F., 2006, The United Nations System: A Reference Handbook. Santa Barbara, CA: ABC-CLIO.

Alger, Chadwick F., 1999 "The Future of Democracy and Global"

Governance Depends on Widespread Public knowledge About Local Links to the World", Cities, Volume 16, No. 3, 195-206.

Anderson, Mary B., 1996, Do No Harm: How Aid Can Support Peace Or War. Boulder/London: Lynne Rienner.

Appleby, R. Scott, 1999, The Ambivalence of the Sacred: Religion, Violence and Reconciliation. Boston, MA: Rowan and Littlefield

Avery, Christopher L., 2000, Business and Human Rights in a Time of Change. London: Amnesty International.

Galtung, Johan, 1980, The True Worlds: A Transnational Perspective. New York: The Free Press.

Jeong, Ho-Won, 2000, Peace and Conflict Studies: An Introduction. Aldershot, UK: Ashgate.

Keck, Margaret E., and Kathryn Sikkink, 1998, Activists Beyond Borders: Advocacy Networks in International Politics. Ithaca, NY: Cornell University Press.

Warah, Rasna, 2001, "The Emerging "Urban Archipelago". United Nations Chronicle: On Line Edition, Vol. XXXVIII, No. 1.

Wenger, Andreas, and Daniel Mockli, 2003, Conflict Prevention: The Untapped Potential of the Business Sector. Boulder, Colorado: Lynne Rienner. 